\title{
FILMING AYAT-AYAT CINTA The Making of a Muslim Public Sphere in Indonesia'
}

\author{
Ahmad Nuril Huda \\ UIN Maulana Malik Ibrahim, Malang - Indonesia
}

\begin{abstract}
This paper examines how the film's public screening of the novel Ayat-ayat Cinta shapes an Indonesian Muslim public sphere in which the notion of religious authority is re-created. It operates on three levels: first, the audiences' perception of the film as a da'wah and their reactions toward the film's contents; second, the rivalry between the novel writer and the film director on particular issues distancing the film from its novel version; and third, the public debates on the issue of polygamy revealed by the film. The paper finds out that the film Ayat-ayat Cinta has arguably invited Muslim people to have their religious teaching in cinema. More importantly, the wide publication of the film on the internet and mass media has enabled all individuals to take part in the debates raised by the film. In these debates, participation is widely open to all, and argumentation is not based on superiority.
\end{abstract}

Keywords: Ayat-ayat Cinta, public sphere, and fragmented religious authority.

\section{Introduction}

After the 1998 Indonesian Reform, the development of Indonesian cinema becomes very dynamic. Its dynamicity is partly indicated by the increasing number of Indonesian film productions, one of which is the Islamic genre film. The most recent evidence of this is Hanung Bramantyo's Islamic film Ayat-ayat Cinta, which is an

\footnotetext{
1 This paper is part of my Master's thesis entitled "When Ayat-ayat Cinta Goes to Cinema: A Moving Picture of Da'wa, Politics and Fragmented Religious Authority," submitted to the Program of Islamic Studies, the Faculty of Humanities, Leiden University, 2009.
} 
adaptation of a national best-selling novel with the same title written by Habiburraman el-Shirazy.

The film starts with the description of the main character, Fahri, an Indonesian graduate student at Al-Azhar University, coming from a poor family in Central Java. He is depicted as a devout Muslim having excellent understanding of Islam, memorizing by heart all the verses of the Qur'aæ, and having the ability to speak four international languages; Arabic, English, French, and German. His language skills allow him to earn money from translating works written in those four foreign languages into Indonesian, in order to pay for his life and education in Egypt. Even though, for religious reasons, he does never intend to have any love relationships with any woman before marriage, his perfect character is reason enough for any woman to fall in love with him. Everywhere he goes, he becomes the center of attention and is adored by many women different in character, such as Maria, Nurul, Noura, and Aisha. In the end, Fahri is severely confused by the circumstances forcing him whether to choose a monogamous or polygamous family.

The film's public screening was a phenomenon. Not only did it acclaim huge popularity, but also it was watched by the members of jama'ah pengajian muslimah (Islamic learning group for women Muslims) and other veiled Muslim women who were not used to attending a movie theatre. ${ }^{2}$ In a somewhat assertive sentence, the film was not only successful in attracting non-movie goers to go to the cinema but was also successful in having the members of Islamic learning groups take their religious lesson from the cinema. At this point, it is significant to question the extent role of the film in functioning as a da'wah or Islamic propagation.

Eickelman and Anderson argue that the proliferation of new media, including film, in the Muslim world has significantly triggered a new sense of Islamic public sphere in which a new mode of Muslim people, Islamic thinking, and Islamic religious authority are set up. ${ }^{3}$ The easy accessibility and proliferation of electronic media facilitate the

\footnotetext{
2 Dahono Fitrianto, "Pembuktian Sebuah Dongeng Cinta," Kompas. Sunday, 2 March 2008.

${ }^{3}$ Dale F. Eickelman and John W. Anderson (eds), New Media in the Muslim World; The Emerging Public Sphere (Bloomington and Indianapolis: Indiana University Press, 1999), pp. 1-19.
} 
constitution of a new Muslim public to challenge both the state and conventional religious authorities, to build civil society, and to engage in international relations. ${ }^{4}$ In this new public sphere, every single person, irrespective of his/her socio-religious background, may have the same chance in shaping public opinions on religious debates.

This paper, taking up Eickelman and Anderson's ideas, aims at investigating the role of the film Ayat-ayat Cinta in establishing a new public arena in which the notion of religious authority is re-created by the Muslim public. The focus is on three different levels of circulation; the audience's perception of the film as a da'wah, the debate between the novel writer and the film director about what separates the novel from the film, and the national debate about the issue of polygamy provoked by the film. To do so, I will first try to elaborate the characteristics of the public sphere and religious authority in modern society.

\section{Discerning Muslim Public Sphere}

The novel Ayat-ayat Cinta has its own audience. ${ }^{5}$ When it was first published as a series in daily newspaper, the readers are perhaps the first audience. When it was turned into a book, the novel gained a wider public response because of the increasing number of its readers. Once it was filmed, its audience was subsequently multiplied. However, in order to understand the characteristics of the audience of Ayat-ayat Cinta we should first understand the characteristics of public in a modern society.

The idea of public sphere pioneered by Jürgen Habermas can help us understand the characteristics of the public in a modern society. By analyzing the $18^{\text {th }}$ Century European bourgeoisie's sociality in coffee houses (Great Britain), salons (France) and table societies (Germany), Habermas defines public sphere as a public realm in which people meet on an equal basis which enables them to form a public opinion. Access is guaranteed for all since authority is constructed neither by social nor by political stratum, but by rationality. In this realm, the

4 Birgit Meyer and Annelies Moors (eds), Religion, Media, and the Public Sphere (Bloomington and Indianapolis: Indiana University Press, 2006), p. 5.

${ }^{5}$ Michael Warner, "Publics and Counter publics," Public Culture 14, 1 (2002), p. 49. 
printing culture becomes one of the most important means for mediating this modern sociality. ${ }^{6}$

Habermas' notion of public sphere coincides with Warner's concepts of a public. According to him, a public of a certain text in a modern society comes into being in relation to the text and its circulation. This kind of public has a number of characteristics. First, the public is self-organized. It exists by a virtue of being addressed. Such a text, for instance, started to have a public once it was published. Second, the public is constituted by mere attention; this public is based on a relation between strangers. A text is addressed to an indefinite number of strangers who are united by the criteria of territory, identity, belief, or some other forms of membership. Since their contact is not based on face-to-face interaction, their relation in turn forms a "nonpresence" society. Third, the public is interconnected through "circulation". Since it is not texts themselves that create the public but the concatenation of texts through time and the way they circulate, the forms of mediation involved and how this mediation takes place are important matters for the understanding of the public. ${ }^{7}$

However, the early Habermas has excluded the role of religion in the development and expansion of the public sphere. ${ }^{8}$ This, in turn, invited a number of researches to investigate the role of religion in the public sphere. ${ }^{9}$ Eickelman and Anderson in their investigation of the proliferation of easily accessed media argue that these increasingly open and accessible forms of communication play a significant role in fragmenting and contesting political and religious authority. These media have formed a so-called "new Muslim people" whose thinking is renewed and recreated by these technological media. The conjuncture between new media, new Muslim society and new ways of thinking about Islam has broad implications, including the emergence of a new

${ }^{6}$ Jürgen Habermas, The Structural Transformation of the Public Sphere (Cambridge: Polity Press, 2008), pp. 32-43.

7 Warner, "Publics and Counter publics," pp. 49-90.

8 Dale. F. Eickelman and Armando Salvatore, "The Public Sphere and Muslim Identities," European Journal of Sociology, 43 (2002), p. 96.

9 Eickelman and John W. Anderson (eds), New Media in the Muslim World.; Miriam Hoexter, Shmuel N. Eisenstadt and Nehemia Levtzion (eds), The Public Sphere in Muslim Society (New York: State University of New York Press, 2002); Armando Salvatore and Dale F. Eickelman (eds), Public Islam and the Common Good (Leiden: EJ. Brill, 2004); Meyer and Moors (eds), Religion, Media, and the Public Sphere. 
religious public sphere. ${ }^{10}$ Furthermore, Hirschkind maintains that Islam is omnipresent in the Egyptian public sphere through sound. ${ }^{11}$ His thick description of the taxi conversation in reaction to the cassette sermon that the taxi driver played, describe how religious authority is re-contested in Muslim public sphere. In addition to this, an effort to redefine the public sphere has been done. Eickelman and Salvatore emphasize on the public sphere as "a site where contest takes place over the definition of the 'common good', and also of the virtues, obligations and rights that members of society require for the common good to be realized". ${ }^{12}$ Moreover, Hirschkind understands public sphere as 'a domain for both subjection to authority and the exercise of individual reasoning. ${ }^{13}$

\section{Religious Authority in Modern Society}

What is religious authority? Who can speak for religion in an authoritative manner? Religious authority is a bewildering concept. The word authority in the English Oxford dictionary is defined as: (1). power to give orders and make others obey, (2) person or group having the power to give orders or take action, and (3) person with special knowledge. ${ }^{14}$ This definition leads us to the assumption that authority is related to power. However, Mark Weber defines authority as being different from power. For him, unlike power, authority, functioning in the absence of coercion, is related more closely to charisma. ${ }^{15}$ Following Weber's definition, Gaborieau defines religious authority as the right to impose rules which are deemed to be in consonance with the will of God. ${ }^{16}$ Nonetheless following the same Weberian definition, Krämer and Schemidtke argue that in present

\footnotetext{
${ }^{10}$ Eickelman and John W. Anderson (eds), New Media in the Muslim World, pp. 1-18.

${ }^{11}$ Charles Hirschkind, "Cassette Ethics: Public Piety and Popular Media in Egypt," in Meyer and Moors (eds), Religion, Media, and the Public Sphere, pp. 29-51.

12 Eickelman and Salvatore, “The Public Sphere," p. 94.

${ }^{13}$ Hirschkind, "Cassette Ethics," p. 47.

14 AS. Hornby, Oxford Advanced Learners Dictionary of Current English, 4th Edition (Oxford: Oxford University Press, 1989), p. 67.

15 See Martin Albrow, Max Weber's Construction of Social Theory (New York: St. Martin's press, 1990), pp. 165-173.

16 Marc Gaborieau, The Redefinition of Religious Authority among South Asian Muslim from 1919 to 1956 (Conference Paper, Bogor, July 2005), p. 1.
} 
time, the difference between authority and power is increasingly blurred. They say that "religious authority can assume a number of forms and functions: the ability (chance, power, or right) to define correct belief and practice, or orthodoxy and orthopraxy, respectively; to shape and influence, marginalize, punish or exclude defiance, heresy and apostasy and their agents and advocates."17

According to the widely perceived view, religious authority in "traditional" Muslim societies usually rests within the body of "ulama who are regarded as authoritative individuals to speak about Islam due to their sufficient knowledge of the interpretation of the sources of religious authority: the Qur'a and sunnah. In constructing their religious authority, "ulama employed a variety of means one of which is commentary. Since the medieval work on Islamic law was open texts requiring interpretation, ${ }^{19}$ commentaries have been employed by ulama $>$ to adjust the text according to the changing socio-political conditions of the ummah, which allowed them to preserve the identity and authority of their school of law and their legal tradition. ${ }^{20}$ The other means is religious advice called fatwa $>$ These are issued either as an answer to a question about a fatwa $\rightarrow r$ as a response to a certain social phenomenon. Fatwa thas been an instrument for 'ulama $>$ to preserve their religiously authoritative positions.

However, in the modern society, religious authority is not only "embodied in texts, individuals, groups of people or in institutions," 21

17 Gurdun Krämer and Sabine Schmidtke (eds), Speaking for Islam: Religious Authorities in Muslim Societies (Leiden: Brill, 2006), p. 1.

18 See R. Stephen Humprheys, Islamic History: A Framework for Inquiry (London - New York: I.B. Tauris \& Co. Ltd, 1991), pp.187-208. In many cases throughout the history of Islam, religious authority has been also exercised by a variety of individuals such as sultans or political leaders and sufis. Political leaders subjected to religious authority are usually those who are, in the same way, fulfilling the role of 'ulamà' like in the case of Maududi in Pakistan, seeGaborieau, The Redefinition of Religious. Meanwhile sufis have been the locus of religious authority for their role as channels between the profane and the divine, see Annablle Böttcher, included in Krämer and Schmidtke (eds), Speaking for Islam, pp. 241-268.

19 Brinkley Messcik, The Calligraphic State: Textual Domination and History in a Muslim Society (Berkeley: University of California Press, 1993), pp. 30-36.

20 Muhammad Qasim Zaman, The Ulama in Contemporary Islam: Custodian of Change (Princeton and Oxford: Princeton University Press, 2002), p. 38.

${ }^{21}$ Nico J.G Kapten, "The Voice of the 'Ulama: Fatwas and Religious Authority in Indonesia," Archives de Sciences Sociales des Religions 125 (Janiver-mars 2004), p. 115. 
but it is challenged by a variety of notions. The proliferation of mass media, video cassettes, television, and internet is particular to the globalizing modern society, and has generated a changing mode of construction of religious authority. Religious texts are published in mass media such as magazines and newspapers. On many occasions, people hear religious sermons on tape recorders, and also watch religious preachers delivering their religious learning as well as Islamic drama on television. This new emerging mode of Islamic publication (media) has generated a new Muslim public in which religious authority is widely contested.

Kaptein's study of the Indonesian fatawa shows that there was a difference in outlook between the fataw $\bar{a}$ issued at the end of the nineteenth century and those issued at the end of the twentieth century. He concludes that as a result of mass education and the growing literacy, non religiously-educated specialists start to be involved in religious debates, and participate in shaping a new religious authority. ${ }^{22}$ Jajat Burhanuddin in his investigation of the impact of Islamic publication on the Muslim public space of $20^{\text {th }}$ century Indonesia found that the printing culture had led to the creation of a space within which Muslims with different religious educational backgrounds and orientations became involved in a struggle to define Indonesian Islam..$^{23}$ This meant that religious authority was no longer monopolized by 'ulama $\rightarrow$ ut it was challenged by writers of articles and books, due to the fact that oral tradition, the traditionally established mode for transmitting Islamic knowledge, began to be replaced by written texts.

\section{The Film Ayat-ayat Cinta, Da'wah, and Muslim Public}

The greater part of Indonesian film audiences consists of young people. According to Subagyo, the overwhelming majority of the late 1970's Indonesian moviegoers were in the 15 to 24 age range. ${ }^{24}$ This did not change in recent time. As indicated by Eric Sasono, going to

\footnotetext{
22 Ibid., pp. 115-130.

${ }^{23}$ Jajat Burhanuddin, "The Fragmentation of Religious Authority: Islamic Print Media in Early 20th Century Indonesia," Studia Islamika 11, 1 (2004): pp. 23-62.

${ }^{24}$ Quoted in Karl G. Heider, Indonesian Cinema: National Culture on Screen (Honolulu: University of Hawaii Press, 1991), p. 21.
} 
the cinema is part of a life style for people aged between 15 and $35 . .^{25}$ The teenage-themed films which dominated the Indonesian cinema indicated that young people are the great majority of the Indonesian film audiences.

Nonetheless, mature people are considered to be part of the audience as well. In the writer's experience, few adults go to cinemas with their nuclear families. Moreover, Indonesian films are currently available in various digital media which enable wider audiences to easily access these films. They are not only screened in the cinemas but are also available on VCD and DVD. Several films are also broadcast on some of the national and local television channels, which means that a broader audience can possibly watch the film. Since the internet become increasingly popular, a number of national films are placed on several websites, such as You Tube and other private blogs, where the audience can easily download the film. Moreover, a film festival can be another way for the audiences of Indonesian films to watch national cinema.

The film Ayat-ayat Cinta was screened in the XXI (twenty one) cinema business network affiliated to Subentra Group. One hundred copies were made of the film, or almost ten times more than any other national film. The film was seen by no less than 3.7 million people. ${ }^{26}$ The number of its audience, in fact, might have been much bigger than what was reported in the media, since few days before the film's premiere, a pirated version of the film had been widely distributed on the internet. In addition, the film was screened in various international film festivals such as the Cannes Film Festival in France, the Indonesian Film Festival in the Netherlands and Prague. It was also screened in mobile cinemas in Palembang. ${ }^{27}$ International news broadcasters such as BBC London herald the film.

The situation of the film screening inside the cinema deserved analysis. "...The spectators occupied about 90 per cent of the seatsreaching until the front seats-during "the least popular screening time"

\footnotetext{
${ }^{25}$ Eric Sasono,"Dua Tahun Transisi Perfilman Indonesia; Catatan untuk Tahun 20052007," in J.B. Kristanto, Katalog Film Indonesia 1926-2007 (Jakarta: Penerbit Nalar, 2007), p. x.

${ }^{26}$ Fitrianto, "Pembuktian Sebuah Dongeng Cinta".

27 Taufik Wijaya, "AAC Keliling Kampung Lewat Layar Tancap di Palembang," www.detiknews.com, 2008 (accessed on 10 January 2010).
} 
between 15:40 and 18:20 pm. Most spectators were women, some were wearing head covers. During the last screening of the film, there was a significant number of spectators either applauding or shedding tears." 28 People had to stand in a long queue in order to get the ticket. A considerable number of members of jama'ah pengajian muslimah as well as a group of Muslim women students and civil servants still wearing their uniform were also among the crowds of spectators. This indicates that the audience of the film come from a variety of backgrounds. The film was watched not only by young movie-goers, but also by people who were not used to attending a film screening in the cinema.

More importantly, the survey of the members of the Islamic learning group, or pengajian, in Agung Mosque, Bandung, conducted by a volunteer for this research found that out of 40 members of the pengajian, almost 20 percent watched the film. Most of them were between thirty and sixty years old. In addition, four of them admitted watching the film in the movie theater, while the rest watched it in their homes. This rough data indicates that the film was not only successful in attracting moviegoers from different backgrounds to go to the cinema but also successful in getting the members of Islamic learning groups to have their religious lesson in a cinema.

What is more striking is that although more that 80 percent of the moviegoers argued that the film contains Islamic da'wah values, the majority denied having the film as either their religious reference or influencing their religious views. The optimistic toned conclusion from this data would be that the members of the pengajian might not regard the film as their authoritative religious reference; however, their responses saying that the film contains religious values and messages indicate that the film could, to some extent, act as a da'wah.

This fact is worth linking with the audiences' responses toward the film. Below, it needs to mention two out of many responses, which represent the general tones of the responses to the public screening of the film which was sent to Hanung Bramantyo's private blog where he posts his personal diary during the production of the film.

"It would be better if Mas Hanung wants to really learn about Islam again. I supported your desire to save this film. But please don't do it hesitantly. Save this film completely. Make an exotic film, yet it's really Islamic: neither a film

${ }^{28}$ Fitrianto, "Pembuktian Sebuah Dongeng Cinta". 
containing an arrogantly holly preacher nor a film exploiting the teenage world. I have watched the film trailer. Honestly, there were some scenes that disappointed me and ruined my hopes for this film. Why on earth should there be "touchy" scenes? Like when Aisha (or perhaps Maria) touch Fahri's chest. This is completely unsuitable for Islam. And even though it was part of the film, it destroyed the beauty of this (Islamic) film".

"Subhanallah. I have watched the film. For me AAC [the film] is a good film. It's an exemplary film for the young people of this era, who have been penetrated by negative western cultures that are not based on Islam and the Qur'an. I give my respect to Mas Hanung and hope there will be more films like this one that are made in the near future, and (those films) can be used as enlightening films for the heart. I pray for Mas Hanung may he be able to produce films which are Islamic and can educate the Indonesian young generation in order to love Islam".

As a matter of fact, the audiences' reactions to the film were not only posted in Hanung's Bramantyo blog, but also in various news websites, such as in www.detiknews.com, www.kompas.com, www.thejakartapost.com and www.liputan6.com, and in some private blogs, where the discussions about the film can be found. Responses from the audience were also found in some magazines ${ }^{29}$ and newspapers. ${ }^{30}$ Ahmad Sarwat's writing in one of the rubrics in www.eramuslim.com which was cited in www.achmadarifin.wordpress.com is worth to be analysed. In an article, entitled "Kontroversi Film Ayat-ayat Cinta" [The controversy of the film Ayat-ayat Cinta], he generally argues that the film was not Islamic since too many Islamic messages developed in the novel were

29 Surat pembaca, "Ayat-ayat Cinta: Setitik Cahaya Perfilman Indonesia," Sabili, 17 April 2008, pp. 8-9.

30 Reiny Dwinanda, “Ayat-ayat Cinta: Dilema Novel ke Layar Lebar," Republika, 2 March 2008, p. 9.

32 "Being the one who is trusted to be the househusband-even though without the housewife-I have to carefully manage all the needs and the prosperity of my house mates. In this flat, the five of us live together; Saiful, Rudi, Hamdi, Mishbah and I. It is by chance that I am the oldest of all, and the one who has been living in Egypt the longest. Academically, I am the highest standing too. While I am just waiting for the approval to start writing my Master's thesis in Al-Azhar, the others are still doing their Bachelor's degree" See, Habiburrahman El-Shirazy, Ayat-ayat Cinta: Sebuab Novel Pembangun Jiwa (Jakarta: Republika Press and Pesantren Karya Basmala, 2004), p. 5. 
significantly reduced by the film. This article has openly been discussed by other bloggers, criticising the film.

Such responses describe the general audiences' reactions, whether supporting or rejecting the Islamic values developed by the film. What is more interesting to discuss is, however, the question of how the audiences of the film could give their responses to the film and how they can shape their arguments. Those responses could not be addressed without the media. Their eagerness to voice their reaction toward the film has been, to some extent, inspired by Hanung Bramantyo posting his personal notes about the film production on his private blog.

\section{Contesting Authority:}

\section{The Novel Writer versus The Film Director}

The character of Fahri in the film is different from the one in the novel. In the novel, Fahri appears not only as the oldest among his other five house mates, but also as the leader of the house..$^{32}$ In the film, however, the relation between Fahri and his house mates is shown as more fluid than in the novel. Their smooth verbal and nonverbal expressions indicate that their relationship was less hierarchical and more equal. ${ }^{33}$ If the novel portrayes the perfection in knowledge, leadership, and behavior of Fahri with his mastery of four languages, Hanung depicts Fahri's "perfection" with some flows of character such as less confident and less superb.

This difference was neither accidental nor by ignorance from the film director. The perfect character of Fahri developed in the novel by Habiburrahman was perceived by Hanung as unrealistic. ${ }^{34}$ To him, there might have been a lot of devoted Muslims remembering by heart all the verses of the holy Qur'ał and a great number of smart Muslim students speaking more than four international languages fluently. But, if those characteristics were accumulated in one person, let alone if the person is being chased by many beautiful girls, it does not seem believable according to Hanung. Therefore, in collaboration with Salman Aristo, the first thing Hanung did before setting up the

\footnotetext{
33 See Hanung Bramantyo, Ayat-ayat Cinta, CD1, Scenes minute 01:15 to 04:23.

34 Hanung Bramantyo, "Ayat-ayat Cinta: Tentang Karakter Fahri”, wmw.dearestmask.blog.friendster.com, 2007 (accessed on 25 January 2010). The same criticism was widely spread among a number of the readers of the novel.
} 
storyline of the film was reconstructing the character of Fahri to be as humanistic as possible.

In response, Habiburrahman denies that the character of Fahri is perfect since he has such humanistic characters as his tendency to be tearful. He says, "So few are the good characters in Indonesian stories that once a character like Fahri appears, it is deemed unrealistic." 35 To support his argument, he mentions a number of great Indonesian figures such as Agus Salim who could speak nine international languages without having any experience of university studies. Furthermore, he confesses that the character of Fahri was a combination of some really existing figures. Besides Agus Salim who was the inspiration for Fahri's linguistic ability, Kyai Munawir Krapyak has been the inspiration for his great knowledge of the Qur'ał. Meanwhile, Abdul Halim Mahmoud, a rector of Al-Azhar University inspired Fahri's smartness and confidence. ${ }^{36}$

Despite Hanung's confession that the reconstruction was not meant as disrespect of the character of Fahri as created by Habiburrahman in the novel, this different depiction of Fahri offers a number of reflections. First, the production of the film allowed the film director to challenge the authority of the novel writer. This is because both individuals have a very different background in religious education. Habiburrahman grew up in a traditional religious family. He obtained his entire education from religious institutions, starting with pesantren, ${ }^{37}$ madrasah, ${ }^{38}$ and finally Al-Azhar University where he acquired some legitimacy to speak on religious matters. Meanwhile, Hanung Bramantyo "only" completed his formal religious education from a Muhammadiyah institution and Mushola ${ }^{39}$ when he was a kid

\footnotetext{
35 Interview with Habiburrahman El-Shirazy, "Kenapa Fahri kok Sempurna Banget," Bagian 1 www.youtube.com, 2008 (accessed on 26 January 2010).

${ }^{36}$ Interview with Habiburrahman El-Shirazy, "Kenapa Fahri kok Sempurna Banget," Bagian 2 wnw.youtube.com, 2008 (accessed on 26 January 2010).

37 While he was studying in pesantren, he also attended lessons in Islamic elementary and junior high school.

38 What I meant by madrasa here is the Islamic Senior High School for the Special Programme called MAPK (Madrasah Aliyah Program Khusus) in which Habiburrahman acquired the modern way of religious learning along with the obligation to speak in Arabic and English, not to mention the encouragement to memorize the Qur'an.

${ }^{39}$ It could be associated with mosque, in a sense that it has a smaller scope.
} 
that gives less religious classes than the the combination of pesantren, madrasah, and Al-Azhar University.

Second, how both people construct their arguments is an important matter to be highlighted. To support his novel with authoritative arguments, Habiburrahman cited a number of standard religious books as references. ${ }^{40}$ This did not prevent Hanung, however, from citing a number of verses from the Qur'aßaccording to his own interpretation. For instance, after explaining his opinion about the character of Fahri, he mentions in his last blog, the Qur'aæ 21:18, written in Indonesian transliteration, along with its Indonesian translation. This diferent way of citing indicates that the argument which is constructed by both individuals remains open for further contestation.

\section{Polygamy as A Contest of Authorities}

Polygamy has been a socially problematic issue in Indonesia. Even though it is in some circumstances permitted in Islamic law, and has been practiced by many Muslims including the 'ulama ; there has been heated debates about it. A great number of women movements condemn this kind of marriage due to the high risk of violating the rights of women and children of polygamous families. The majority of Indonesian society is also against this form of marriage. Farihah and Heriyanto's research about public opinion regarding polygamy in Ciputat, Tangerang district, shows that among 125 respondents, about 62 percent disagree with polygamy. ${ }^{41}$ The Jakarta Post also reported that during 2006, the data from the national court indicated an increasing number of divorces caused by the wives disagreeing with their husbands' marriage with another woman. ${ }^{42}$

Nonetheless, the widespread debate about this issue first started in 2003, and was provoked by the controversial polygamy award granted by a fried chicken franchise businessman Puspowardoyo. No less than

${ }^{40}$ For example Al-Sunnah wa al-Bid'ah, Al-Tadzkira, Fatawa Mu'ashirah, Makanat alMar'ah fi al-Islam, Tuhfa al-'Arus aw al-Zawaj al-Islamy al-Sa'id, and Tubfah al-'Aris wa al'Arus (the transliteration used here is based on those written in the novel's bibliography, see El Shirazy, Ayat-ayat Cinta, pp. 404-5.

${ }^{41}$ Ipah Farihah and Heriyanto, Pandangan Masyarakat Terhadap Poligami dan Dampaknya Terbadap Keluarga (Jakarta: UIN Jakarta Press, 2007), p. 86.

42 Abdul Khalik, "Women Reject Polygamy, Choosing Divorce," www.thejakartapost.com, 2009 (accessed on 26 January 2010). 
30 women movements in Jakarta protested against the award ceremony ${ }^{43}$ in addition to a number of articles that appeared in the mass media condemning the award as an insult to woman's dignity. ${ }^{44}$ The award also invited some Muslim scholars to redefine the textual sources of the Qur'aæ and H\{di concerning the practice of polygamy. For instance, a gender rights activist and professor of Islamic political thought at the State Islamic University (UIN) of Syarif Hidayatullah Jakarta, Siti Musdah Mulia, published a book in which she argues that polygamy is not compatible with the spirit of Islam in modern society, and that Indonesian marriage law legalising some kinds of polygamy should be revised. ${ }^{45}$ Other people from a variety of backgrounds were also encouraged to get involved in the public debates through a wide range of public media, including the film.

In the midst of the cotrovercy over polygamy, the film Ayat-ayat Cinta is partly concerned with this sensitive issue. In this context, the problematic and sensitive public debate about the message of polygamy developed in the film could probably give rise to public fragmented religious authorities. Compared to its novel version, the film gives more attention to polygamy. When being asked about the main message of the film, most of the members of the Islamic learning group in Agung Mosque who had watched the film mentioned the issue of polygamy as a significant plot. In his interview, Hanung Bramantyo also admitted that polygamy has been his main message in this film. He stated that he wanted to draw the attention of the audience to the Islamic universal theme of love which ended up in polygamy. ${ }^{46}$ This emphasis was triggered by the public debates on the issue.

The issue of polygamy can be easily found in the story line of Ayatayat Cinta. Fahri, being jailed for rape accusation, is forced by Aisha to marry the unconscious Maria, the only witnesses able to free Fahri from the accusation. From the film scenes, three reasons can be

\footnotetext{
${ }^{43}$ Faiza Mardzoeki, "We are Against Polygamy," www.thejakartapost.com, 2009 (accessed on 13 January 2010).

44 Lily Zakiyah Munir, "Querying Polygamy Award," www.thejakartapost.com, 2003 (accessed on 15 January 2010).

45 See, Siti Musdah Mulia, Islam Menggugat Poligami (Jakarta: Gramedia, 2004).

46 Rohmat Haryadi, Saat Bioskop Jadi Majelis Taklim: Sibir Film Ayat-ayat Cinta (Jakarta: Penerbit Hikmah, 2008), p. 216.
} 
drawn. First, their marriage, as suggested by the doctor, could possibly heal Maria from her severe shock from Fahri's marriage with Aisha. Second, Fahri's escape from death sentence is needed because Aisha is pregnant and the baby is in a need of his father. Third, there has been a Muslim character inside the Coptic Maria. However, even though the polygamous marriage was approved by Aisha, in the later scenes it hardly runs smoothly. Fahri is not able to share his love fairly between his wives. While Aisha becomes jealous after discovering that Maria knows Fahri's life more than she does. Aisha flees the house and goes to her uncle's house, and tries to go back to Turkey to visit her mother's grave and calm down her hard feeling. Nonetheless, when Fahri asks her to return home to help him face the polygamous marriage sincerely, she follows him. Finally, the polygamous family is later depicted as a joyful one until the moment when Maria dies and they conduct a congregational prayer. Before she dies, Maria apologizes to Aisha for not being able to differentiate between love and possessive desire.

To get a better understanding of the practices of polygamous marriage, a comparison between this kind of mariage developed in the film Berbagi Suami (Husband for Sharing) produced by Nia Dinata in 2006 and in the film Ayat-ayat Cinta needs to be undertaken. The latter seems to be a counter attack against the former. The former tends to emphasize polygamous family as a sexual domination of the husband over his subordinated wives. Accordingly, it was mainly a sexual reason that pushes the husbands (Bang Haji, Koh Abun and Pak. Lik) towards polygamous marriage. However, the wives are depicted as victims -for the sake of social status or material reasons- even though in some cases Salma, Siti, and Ming finally found their own enlightened ways to escape from polygamy.

In contrast, polygamy in the film Ayat-ayat Cinta is depicted in a more conservative manner. It appears more as a solution for a problem rather than as a condition for conflict. Sexual desire is not seen as a reason for Fahri to practice polygamy; this is indicated by his disapproval of the marriage proposal of Nurul's uncle. Rather, it is a religious and humanistic reason that encourages Aisha to command her husband to marry the Coptic lady. In short, polygamy is by no means widely permitted in this film. The reason is that even though some conflicts occurring in their marriage are always finally solved, the dramatic and complicated conflicts that arise before and after the 
marriage likely betokens the hard life of the polygamous family. Nevertheless, "death" as the solution to the conflict which provides the film's happy ending can strengthen the message. ${ }^{47}$

The intersection of all these facts can bring us to the conclusion that film has enabled the film workers not only to be involved in a public debate about social issues like polygamy, but also to create new public spaces within which a number of authorities are being invited to support their arguments. Furthermore, their arguments are increasingly contested not only from a specific viewpoint but rather from various perspectives. However, religious authority is apparently seen as important in authorizing these arguments, even though the unrelenting debate about the issue of polygamy indicates that no absolute authority actually exists.

\section{Conclusion}

The film Ayat-ayat Cinta is, to some extent, a da'wah kind. However, it is not used by its audience as a primary source of religious authority. Despite that, the public screening has invited Muslim publics to voice their opinions about certain religious issues revealed in the film. Accordingly, the film has created a Muslim public sphere thanks to the internet and other mass publications, where all Muslim people from different religious background are welcome to take part in the debate. Regardless of their authorities, they can all take part in the debate about what Anderson and Eickelman call the common good.

In this realm of public space, authority is no longer monopolized by 'ulama, rather it is contested by many, as the debate about the issue of polygamy developed within the film shows. Furthermore, the argumentation is not based on superiority. Rather, there is no supreme argument that is able to end the debates. It is for this reason that the following quotation needs to be inserted: "Film is "no longer existent only in celluloid, or even in digital code. But film has left the theater house, infiltrated old rituals and fashioned new rituals...Film merges into the public spaces of civic life."48

\footnotetext{
${ }^{47}$ In this regard Ayat-ayat Cinta has followed the legacy of Indonesian films whose narrative plots move from order to disorder and to order again, see Heider, Indonesian Cinema, pp. 34-8.

48 S. Brent Plate, "The Footprints of Film: After Images of Religion in American Space and Time," in Jolyon Mithell and S. Brent Plate (eds), The Religion and Film Reader (New York and London: Routledge, 2007), p. 439.
} 


\section{Bibliography}

\section{Books and Articles}

Albrow, Martin. Max Weber's Construction of Social Theory, New York: St. Martin's press, 1990.

Böttcher, Annablle. "Religious Authority in Transnational Sufi Networks: Shaykh Nāzim al-Qubrusi al-Haqqan̄̄." in Krämer, Gudrun and sabine Schmidtke (eds). Speaking for Islam: Religious Authorities in Muslim Societies. Leiden: Brill, 2006, pp.241-268.

Burhanuddin, Jajat. "The Fragmentation of Religious Authority: Islamic Print Media in Early 20 th Century Indonesia." Studia Islamika 11:1 (2004), pp. 23-62.

Hirschkind, Charles. "Cassette Ethics: Public Piety and Popular Media in Egypt." in Birgit Meyer and Annelies Moors (eds). Religion, Media, and the Public Sphere. Bloomington and Indianapolis: Indiana University Press, 2006, pp. 29-51.

Eickelman, Dale F. and John W. Anderson (eds). New Media in the Muslim World: The Emerging Public Sphere. Bloomington and Indianapolis: Indiana University Press, 1999.

Eickelman, Dale. F. and Armando Salvatore. "The Public Sphere and Muslim Identities.” European Journal of Sociology 43 (2002): pp. $96-$ 115.

El-Shirazy, Habiburrahman. Ayat-ayat Cinta: Sebuah Novel Pembangun Jiwa. Jakarta: Republika Press and Pesantren Karya Basmala, 2004.

Farihah, Ipah and Heriyanto. Pandangan Masyarakat Terhadap Poligami dan Dampaknya Terbadap Keluarga. Jakarta: UIN Jakarta Press, 2007.

Gaborieau, Marc. The Redefinition of Religious Authority among South Asian Muslim from 1919 to 1956. Conference Paper. Bogor, July 2005.

Habermas, Jürgen. The Structural Transformation of the Public Sphere. Cambridge: Polity Press, 2008.

Haryadi, Rohmat. Saat Bioskop Jadi Majelis Taklim: Sibir Film Ayat-ayat Cinta. Jakarta: Penerbit Hikmah, 2008.

Heider, Karl G. Indonesian Cinema: National Culture on Screen. Honolulu: University of Hawaii Press, 1991. 
Hoexter, Miriam., Shmuel N. Eisenstadt and Nehemia Levtzion (eds). The Public Sphere in Muslim Society. New York: State University of New York Press, 2002.

Hornby, A S. Oxford Advanced Learners Dictionary of Current English. 4th Edition. Oxford: Oxford University Press, 1989.

Humprheys, R. Stephen. Islamic History: A Framework for Inquiry. London - New York: I.B. Tauris \& Co. Ltd, 1991.

Kaptein, Nico J.G. "The Voice of the "Ulama: Fatwas and Religious Authority in Indonesia." Archives de Sciences Sociales des Religions 125 (Janiver-mars 2004): p. 115-130.

Krämer, Gudrun and Sabine Schmidtke (eds). Speaking for Islam: Religious Authorities in Muslim Societies. Leiden: Brill, 2006.

Messcik, Brinkley. The Calligraphic State: Textual Domination and History in a Muslim Society. Berkeley: University of California Press, 1993.

Meyer, Birgit and Annelies Moors (eds.). Religion, Media, and the Public Sphere. Bloomington and Indianapolis: Indiana University Press, 2006.

Mulia, Siti Musdah. Islam Menggugat Poligami. Jakarta: Gramedia, 2004.

Plate, S. Brent. "The Footprints of Film: After Images of Religion in American Space and Time." in Jolyon Mithell and S. Brent Plate (eds). The Religion and Film Reader. New York and London: Routledge, 2007.

Salvatore, Armando \& Dale F. Eickelman (ed.). Public Islam and the Common Good. Leiden: Brill, 2004.

Sasono, Eric. "Dua Tahun Transisi Perfilman Indonesia: Catatan untuk Tahun 2005-2007." in J.B. Kristanto. Katalog Film Indonesia 19262007. Jakarta: Penerbit Nalar, 2007.

Warner, Michael. "Publics and Counterpublics." Public Culture 14:1 (2002), p 49-90.

Zaman, Muhammad Qasim. The Ulama in Contemporary Islam: Custodian of Change. Princeton and Oxford: Princeton University Press, 2002.

\section{Films}

Ayat-ayat Cinta

Berbagi Suami 


\section{Newspapers}

Kompas

Republika

Sabili

\section{Electronic Sources}

www.detiknews.com

www.dearestmask.blog.friendster.com

www.youtube.com

www.thejakartapost.com

www.achmadarifin.wordpress.com

www.eramuslim.com

www.liputan6.com

www.kompas.com 